Historical perspective

\title{
Probing the threshold of membrane damage and cytotoxicity effects induced by silica nanoparticles in Escherichia coli bacteria
}

\author{
Marion Mathelié-Guinlet ${ }^{\mathrm{a}, \mathrm{b}}$, Laure Béven ${ }^{\mathrm{c}}$, Fabien Moroté ${ }^{\mathrm{a}}$, Daniel Moynet ${ }^{\mathrm{d}}$, \\ Touria Cohen-Bouhacina ${ }^{\mathrm{a}, \mathrm{e},{ }^{\mathrm{*}}, \mathrm{w}}$ \\ a Univ. Bordeaux, CNRS, LOMA, UMR 5798, 351 cours de la Libération, 33400 Talence, France \\ b Univ. Bordeaux, CNRS, ICMCB, UPR 9048, 87 avenue du Dr Albert Schweitzer, 33608 Pessac, France \\ ' Univ. Bordeaux, INRA, UMR 1332 Biologie du Fruit et Pathologie, 33140 Villenave-d'Ornon, France \\ ${ }^{\mathrm{d}}$ Univ. Bordeaux, INSERM U1035, 146 rue Léo Saignat, 33000 Bordeaux, France \\ e Cellule de transfert NanoPhyNov, ADERA, LOMA, 351 cours de la Libération, 33400 Talence, France
} Christine Grauby-Heywang ${ }^{\mathrm{a}}$, Ibtissem Gammoudi ${ }^{\mathrm{a}, \mathrm{e}}$, Marie-Hélène Delville ${ }^{\mathrm{b}, *}$,

\begin{tabular}{|c|c|}
\hline & A B S T R A C T \\
\hline
\end{tabular}

\section{Introduction}

For the past decades, nanotechnologies field has experienced a fast and growing development in many areas (microelectronics, medical imaging, cosmetics...) because of the specific physico chemical proper ties of nanoparticles (NPs). Though, this enthusiasm began to be questioned as NPs might put environmental safety and human health at risk by interacting with biological systems and affecting their behavior at the cellular level [1 7]. The diversity of NPs in terms of composition, shape and size/diameter $(\Phi)$ challenges politicians for regulating their safe use, and scientists for understanding how they interact with living organisms $[8,9]$. Such regulation and understanding are, though, necessary for the safe development of various applications like diagnosis in medicine [10 12], smart textiles conception [13,14], environmental treatments and detection sensors $[15,16]$.

Among widely used biological systems, Escherichia coli is the most thoroughly studied species of bacteria. Ubiquitous in the environment, E. coli are Gram negative bacteria which, along with the cytoplasmic membrane and a peptidoglycan layer, possess an outer membrane (OM) composed of a phospholipid bilayer, containing lipopolysaccharide (LPS) molecules and proteins [17]. Potential human infections and diseases need to be considered as a consequence of exposure to several E. coli strains. The strain E. coli MRE 162 that we used in this work was first studied during the Lyme Bay trials in 1966 in order to mimic real biological attacks and to determine how United Kingdom (UK) popula tions could be at risk. Releasing massive amount of such bacteria, UK militaries reported chest and blood infections, caused by inhalation of E. coli MRE 162, especially in individuals highly susceptible to disease and exposed to contaminated clouds [18].

Studies on the antibacterial activity of NPs towards other $E$. coli strains showed that diverse metal oxides [19], iron [20] copper and silver [21] based nanomaterials exhibit a bactericidal activity. Major

\footnotetext{
* Corresponding author.

** Correspondence to: T. Cohen-Bouhacina, Univ. Bordeaux, CNRS, LOMA, UMR 5798, 351 cours de la Libération, 33400 Talence, France.

E-mail addresses: marie-helene.delville@icmcb.cnrs.fr (M.-H. Delville), touria.cohen-bouhacina@u-bordeaux.fr (T. Cohen-Bouhacina).
} 
toxicity mechanisms include the disruption of the bacterial membrane integrity leading to the leakage of intracellular components [22], the production of reactive oxygen species (ROS) damaging bacterial con stituents [21] and/or the dissolution of NPs into their constituting ions interfering with the bacterial metabolism [23]. These mechanisms depend on multiple factors (composition, chemical functionalities, shape), especially the size and charge of NPs [29 33]. For instance, Beddoes et al. have presented an overview of in vivo and in vitro studies on human cells, and membrane models simulations, reporting that (i) small NPs (tens of $\mathrm{nm}$ ) translocate very efficiently through the membrane causing cellular damage while large NPs (hundreds of $\mathrm{nm}$ ) exhibit strong cellular uptake without toxicity; (ii) positively charged NPs disrupt membrane integrity and are more toxic than negatively charged NPs [8].

Because of their relatively low toxicity towards eukaryotic cells, their biocompatibility and their easy surface modifications, silica NPs $\left(\mathrm{SiO}_{2} \mathrm{NPs}\right)$ are good candidates for biomedical imaging, drug delivery, and biosensor applications $[34,35]$. Interestingly, $\mathrm{SiO}_{2} \mathrm{NPs}$, not per se but functionalized with either photosensitizing molecules or antibiotics, or anchored to nanohybrid materials are promising both in bacterial detection [36] and antibacterial activity [37]. Despite this great potential, the interactions of non functionalized $\mathrm{SiO}_{2} \mathrm{NPs}$ with bacteria are not well documented in the literature. Most studies on toxicity of such NPs towards microorganisms rely on colorimetric methods or on Colony Forming Units (CFU) counting which allow the quantification of the minimum bactericidal concentration and the determination of the percentage of dead cells $[38,39]$. However, even if the death of cells is a key parameter, their behavior in the presence of bactericidal com pounds is also crucial to investigate and to understand the underlying toxicity mechanisms and to distinguish between the effects of different parameters such as NPs size and charge.

Some authors used transmission electron microscopy (TEM) to observe the morphological damages induced to $E$. coli cells by $\mathrm{ZnO}$ and Ag NPs [40,41]. Confocal Raman spectroscopy molecular inter pretation for such damages was also performed for GaN NPs interacting with different bacterial strains [22]. In this context, atomic force microscopy (AFM) is also another technique which provides comple mentary opportunities (i) to observe biological systems at a nanometer scale, both in air and in physiological environment, and (ii) to probe their nanomechanical properties in real time [42 44]. Under these conditions, AFM is thus a pertinent technique to analyze bacteria morphological and rheological damages induced by potentially anti bacterial agents, such as NPs, with details at the nanoscale.

In the present work, our main objectives were to better understand the process of interaction of $\mathrm{SiO}_{2} \mathrm{NPs}$ with $E$. coli MRE 162, for which, to our knowledge, it is the first study of exposure to NPs. We aimed at determining a potential size and charge threshold, for which $\mathrm{SiO}_{2} \mathrm{NPs}$ would be toxic towards E. coli. NPs of $100 \mathrm{~nm}$ in diameter and larger have been shown to exhibit similar behaviors so that the herein considered range ( $4 \mathrm{~nm}$ to $100 \mathrm{~nm}$ ) will focus on all the opened questions about size dependent biotoxicity of NPs [45,46]. These $\mathrm{SiO}_{2}$ NPs were characterized in terms of size distribution and aggrega tion state in solution. We first quantified the bacterial viability upon incubation with such particles. Then, we focused on how the presence of $\mathrm{SiO}_{2} \mathrm{NPs}$ of different sizes and charges disturbs the bacteria morphology and the mechanical properties of their membrane, by taking advantage of AFM in tapping mode and finally correlated these data with the viability results.

\section{Results}

\subsection{Size and charge characterization of $\mathrm{SiO}_{2} \mathrm{NPs}$}

Dynamic Light Scattering (DLS) measurements (Table 1) revealed that, for the largest $\mathrm{SiO}_{2} \mathrm{NPs}^{-}(\Phi \geq 50 \mathrm{~nm})$, the average hydrody namic diameter was larger than the primary particle sizes obtained by
Table 1

Characterization of $\mathrm{SiO}_{2}$-NPs, both commercial and home-made, by DLS and zeta potential measurements and statistics on TEM pictures.

\begin{tabular}{|c|c|c|c|c|c|}
\hline \multirow[t]{2}{*}{ Name } & & \multicolumn{3}{|l|}{ Diameter (nm) } & \multirow{2}{*}{$\begin{array}{l}\text { Zeta potential } \\
(\mathrm{mV})\end{array}$} \\
\hline & & Manufacturer & TEM & DLS & \\
\hline $\mathrm{SiO}_{2}$-NPs & 4 & 4 (large distribution) & aggregated & 3 & 53.3 \\
\hline $\mathrm{SiO}_{2}$-NPs & 10 & $10 \pm 5$ & $12 \pm 4$ & 7 & \\
\hline $\mathrm{SiO}_{2}$-NPs & 50 & $50 \pm 10$ & $53 \pm 12$ & 68 & \\
\hline $\mathrm{SiO}_{2}$-NPs & 80 & Home made & $81 \pm 4$ & 90 & \\
\hline $\begin{array}{c}\mathrm{SiO}_{2} \text {-NPs } \\
100\end{array}$ & & $100 \pm 30$ & $113 \pm 11$ & 124 & \\
\hline $\begin{array}{c}\mathrm{SiO}_{2}-\mathrm{NPs}^{+} \\
100\end{array}$ & & Home made & $94 \pm 4$ & 135 & +45.4 \\
\hline
\end{tabular}

TEM. On the contrary, for the smallest $\mathrm{SiO}_{2} \mathrm{NPs}^{-}(\Phi<50 \mathrm{~nm})$, it was underestimated as compared to values provided by manufacturers and TEM. Size distributions, obtained by statistics on TEM clichés, suggest that all $\mathrm{SiO}_{2}$ NPs are quite monodisperse (Fig. S1).

Zeta potential measurements (Table 1) indicated that, as expected, bare $\mathrm{SiO}_{2} \mathrm{NPs}^{-}$were highly negatively charged at $\mathrm{pH} 5.5$ resulting in the stability of the suspensions and a minimal aggregation state for these NPs. After functionalization with APS, at pH 5.5, $\mathrm{SiO}_{2} \mathrm{NPs}$ exhibited, as expected, highly positive charges $\left(\mathrm{SiO}_{2} \mathrm{NPs}^{+}\right)$, also resulting in a good colloidal stability.

Thereafter, these well defined $\mathrm{SiO}_{2}$ NPs were studied in interaction with $E$. coli cells (i) at the macroscopic level with viability tests and (ii) at the nanometer scale with AFM observations.

\subsection{Effects of $\mathrm{SiO}_{2} \mathrm{NPs}^{-}$on E. coli cells viability}

The potential antibacterial effect of $\mathrm{SiO}_{2} \mathrm{NPs}^{-}$was estimated by counting CFUs generated after treatment by a solution of NPs at a concentration of $1 \mathrm{~g} / \mathrm{L}$, on LB agar plates, and normalizing them with those of $E$. coli alone (OD $=0.01$, control). Though most of such experiments required buffer solutions, ours were performed in ultra pure water for convenient reasons (AFM characterizations afterwards). No mortality is observed in this solvent (results not shown) in agreement with previous studies showing the strong resistance of $E$. coli in drastic environment, depending on $\mathrm{pH}$ and temperature for instance [47 49]. The development of CFUs is known to depend on two contributions: (i) the initial distribution of the bacteria in suspension and (ii) the toxicity of the environment, i.e. its capability, after potential treatment, to generate a CFU. Thus, the influence of the presence of $\mathrm{SiO}_{2} \mathrm{NPs}^{-}$is investigated under these perspectives.

Under static conditions, two sets of behavior were observed: (i) $\mathrm{SiO}_{2} \mathrm{NPs}^{-} 100$ had no detrimental effect on the bacteria, with a CFU number close to those of the control, while (ii) the presence of smaller $\mathrm{SiO}_{2} \mathrm{NPs}^{-}(4 \mathrm{~nm}$ to $80 \mathrm{~nm})$ did induce an increase in these CFUs (Fig. 1a). In addition, the clustering state of $E$. coli cells upon $\mathrm{SiO}_{2} \mathrm{NPs}^{-}$ treatment was studied by dark field microscopy (see Fig. 1b for representative images). In controls, $E$. coli were present as isolated cells as well as small aggregates. The same organization was observed in the presence of $\mathrm{SiO}_{2} \mathrm{NPs}^{-} 80$ and 100. By contrast, in the presence of $\mathrm{SiO}_{2}$ $\mathrm{NPs}^{-}$4, 10 and 50, the number of isolated cells was increased. Such splitting of cells clusters is likely at the origin of the CFUs increase (Fig. 1c), interactions between such $\mathrm{SiO}_{2} \mathrm{NPs}^{-}$and E. coli being stronger than cell cell interactions. Similar behaviors were observed for $E$. coli incubated with $\mathrm{SiO}_{2} \mathrm{NPs}^{-}$during $24 \mathrm{~h}$, suggesting that their full activity is reached in $2 \mathrm{~h}$ (Fig. S2).

However, this technique appears insufficient to probe any toxicity phenomena of $\mathrm{SiO}_{2} \mathrm{NPs}^{-}$as they could combine, more or less, with splitting effects (Fig. 1c).

Consequently, AFM experiments were carried out to better under stand, visualize and characterize the type of interaction of $\mathrm{SiO}_{2} \mathrm{NPs}^{-}$ with $E$. coli and their potential deleterious effects. 

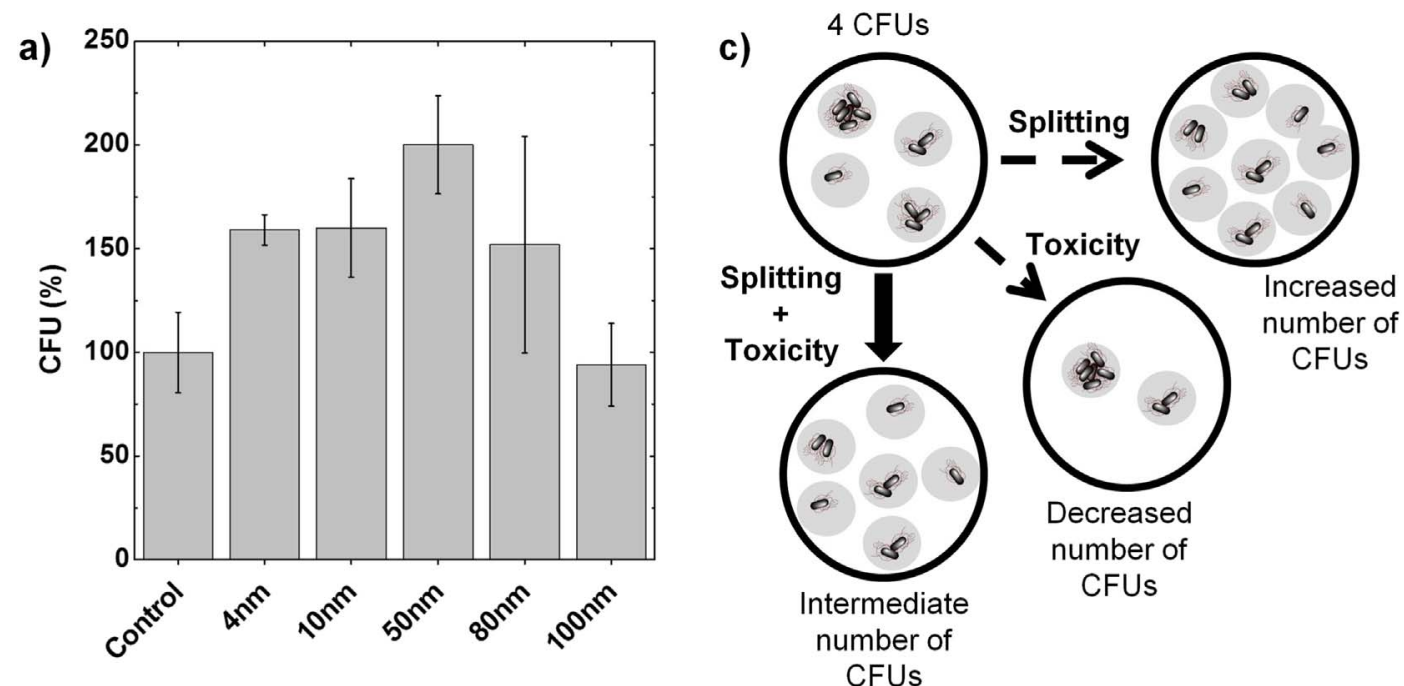

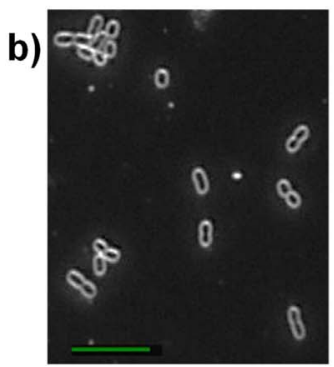

Control

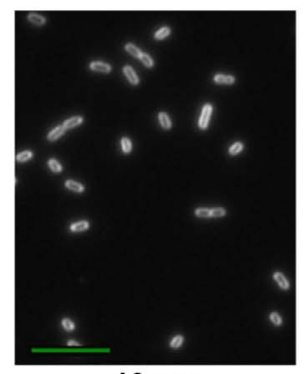

$10 \mathrm{~nm}$

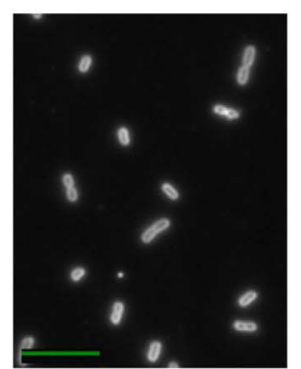

$50 \mathrm{~nm}$

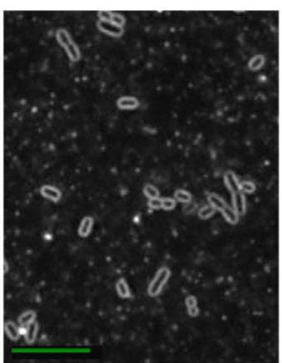

$100 \mathrm{~nm}$

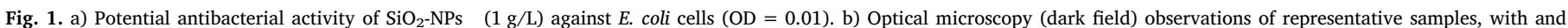

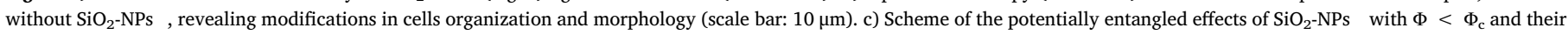
consequences on CFUs.

\subsection{Morphological characterization of E. coli bacteria by AFM}

Before investigating their interactions with $\mathrm{SiO}_{2} \mathrm{NPs}$, the morphol ogy and the structure of $E$. coli cells alone were characterized. In air, $E$. coli bacteria exhibited a typical rod shape, convention name that is widely used for such bacteria [50] (Fig. 2a). E. coli length, width and height were estimated, on average, at $2.0 \mu \mathrm{m}, 1.2 \mu \mathrm{m}$ and $0.3 \mu \mathrm{m}$, respectively. Also, E. coli surface showed a "brain like" aspect not only from the morphology point of view (Fig. 2b) but also from the rheology point of view with nanodomains, referred as "ripples" thereafter (Fig. 2c). The nanodomains were on average $3.9 \pm 1.5 \mathrm{~nm}$ in height and $39.9 \pm 7.4 \mathrm{~nm}$ in width. This particular phase separation pattern is due to the presence of an outer membrane (OM) in Gram negative bacteria. Based on the AFM tip interactions with the sample, phase contrasts on $E$. coli stand for membrane constituents with either different mechanical properties or different molecular organizations: ripples on the one hand and inter ripples on the other hand.

Morphological and structural characteristics of $E$. coli membrane being characterized, its interactions with $\mathrm{SiO}_{2} \mathrm{NPs}$ are hereafter studied, under these perspectives.

\subsection{AFM study of the damages induced by $\mathrm{SiO}_{2} \mathrm{NPs}^{-}$on E. coli cells}

The potential impacts of $\mathrm{SiO}_{2} \mathrm{NPs}$ on the morphology and structure of $E$. coli cells are discussed hereafter, in terms of size dependency. In order to efficiently observe these damages we had to control the quantity of added $\mathrm{SiO}_{2} \mathrm{NPs}$ so as to image both $\mathrm{SiO}_{2} \mathrm{NPs}$ and bacteria the $\mathrm{SiO}_{2} \mathrm{NPs}$ concentration was then reduced from 1 to $0.1 \mathrm{~g} / \mathrm{L}$.

When treated with $\mathrm{SiO}_{2} \mathrm{NPs}^{-}$at a concentration of $0.1 \mathrm{~g} / \mathrm{L}, E$. coli cells were present on the substrate as isolated cells or aggregates, as in untreated samples. All $\mathrm{SiO}_{2} \mathrm{NPs}^{-}$accumulate not only around and on bacteria but also on the substrate, as free isolated or aggregated particles (Fig. 3a b). Because of their higher stiffness, $\mathrm{SiO}_{2} \mathrm{NPs}$ appear as brighter zones than bacteria in phase images, which also show their respective distribution on the substrate (Fig. 3c d).

When exposed to $\mathrm{SiO}_{2} \mathrm{NPs}^{-} 80$ and 100, E. coli cells remained rod shaped and displayed the same height as control cells (Fig. 4a b). By contrast, in the presence of $\mathrm{SiO}_{2} \mathrm{NPs}^{-}$4, 10 and 50, E. coli morphology evolved from rod like to more spherical shape with up to $50 \%$ decrease in their length (Fig. 4c e).

After exposure to large $\mathrm{SiO}_{2} \mathrm{NPs}^{-} 80$ and 100, E. coli cells not only exhibited an unchanged global morphology but also an unmodified phase separation pattern of its envelop, which remained similar to that of healthy unexposed cells (Fig. 5a b and Fig. S3). As soon as smaller $\mathrm{SiO}_{2} \mathrm{NPs}^{-}$(4, 10 and $\left.50 \mathrm{~nm}\right)$ were used, strong detrimental cell membrane reorganizations were observed along with morphological changes. Indeed, the brain like structure of the OM of E. coli was completely altered as compared to the OM structure of unexposed cells (compare Fig. 5a,c and Fig. S3): the ripples nanodomains turned into island like structures and several areas in the OM even lack any regular organization. At this point, the reorganization might arise from either a (i) different molecular packing, i.e. the way molecules of the OM arrange themselves on the surface, or (ii) a different molecular conformation, i.e. the way molecules of the OM self orientate them selves at the air bacteria interface (condensed or fluid conformation).

$\mathrm{SiO}_{2} \mathrm{NPs}^{-}$not only affect the organization of the OM but also its morphology. When $\Phi>50 \mathrm{~nm}$, two behaviors were observed: either (i) $\mathrm{SiO}_{2} \mathrm{NPs}^{-}$were deposited on bacteria or (ii) they were trapped in between two cells (Fig. S4). In the latter case, the ripples nanodomains adapt to the NP shape, changing their orientation around the particle to partially wrap it like a "cocoon" (Fig. 6). The wrapping ratio can change among cells, leaving the NP more or less apparent (compare Fig. 6 and 


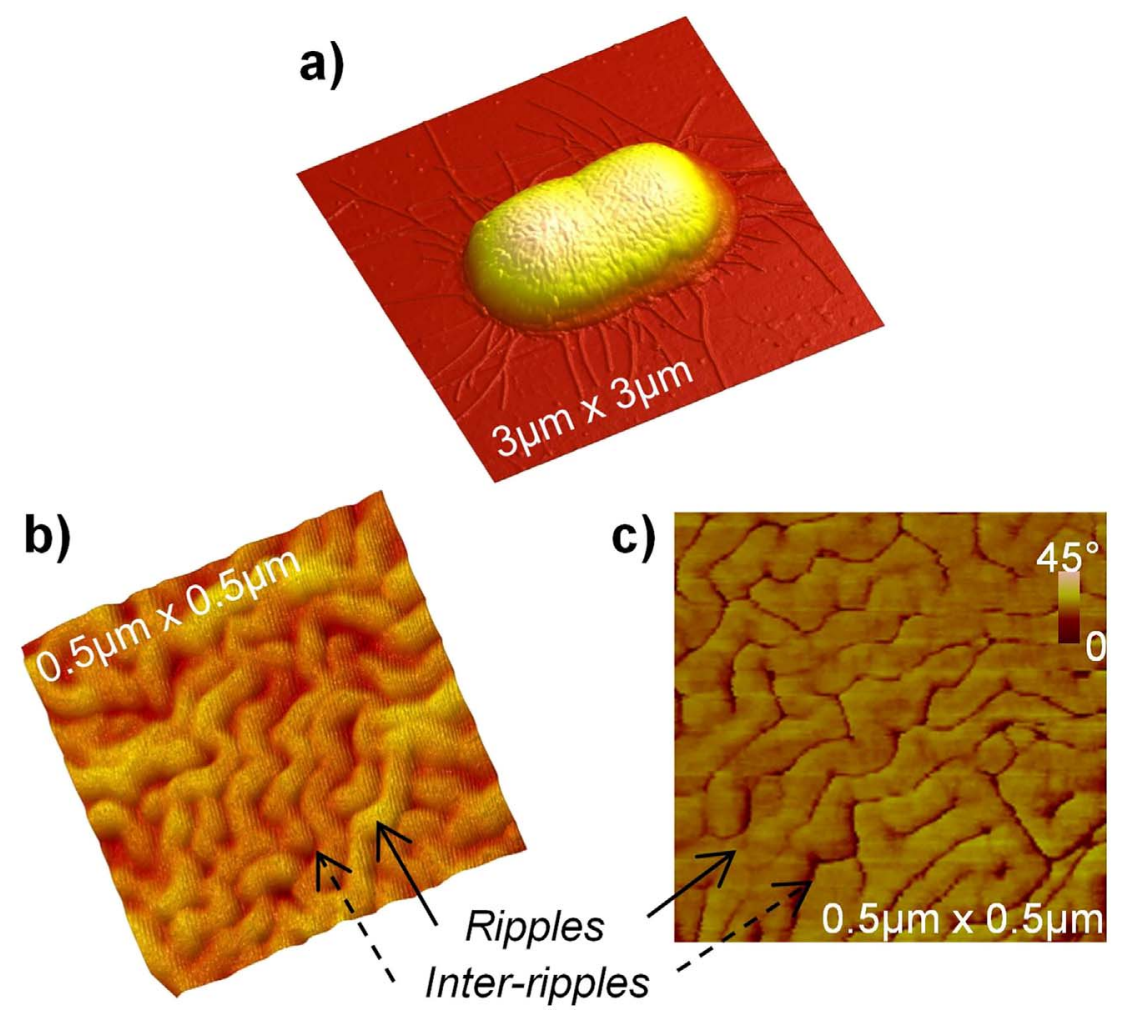

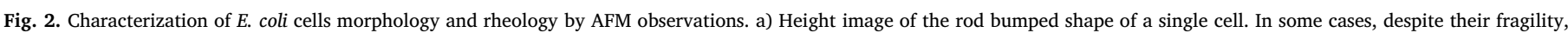

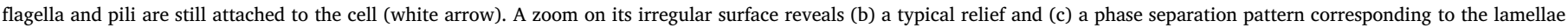
organization of the cell OM.
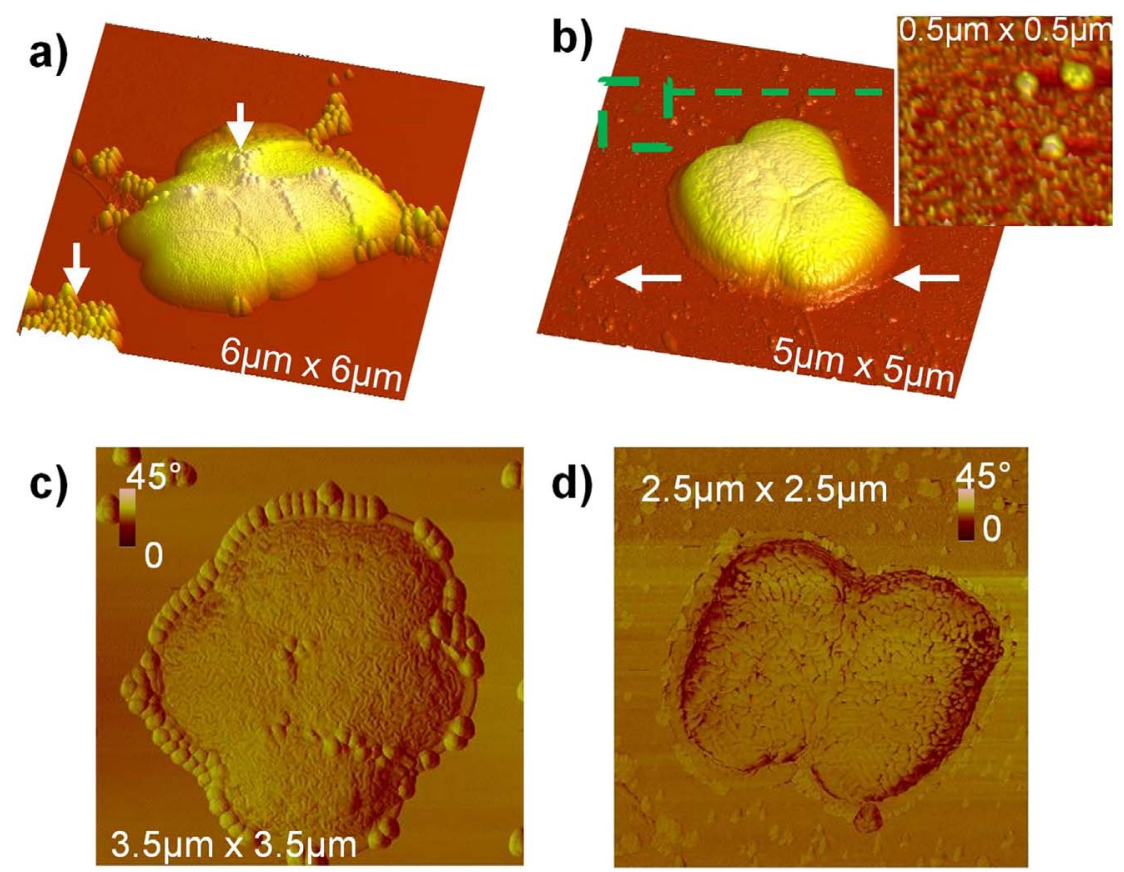

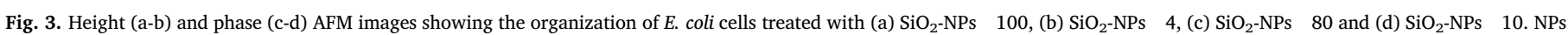
are either deposited on and around cells or free on the substrate (white arrows).

Fig. S5).

When $\Phi \leq 50 \mathrm{~nm}$, membrane invaginations (pore like lesions), with well defined spherical edges, were observed randomly distributed on the bacterial surface (Fig. 7a). Even if cell dependent, their depth could reach down to few tens of nanometers (Fig. S6). Two behaviors are associated to these pore like lesions: either (i) the height profile is linked to a phase signature similar to the OM one or (ii) it exhibits a bump linked to a more repulsive signature similar to the NP one (Fig. 7b c).

We here demonstrated that drastic damages induced by $\mathrm{SiO}_{2} \mathrm{NPs}^{-}$ depend on a critical diameter $\left(50 \mathrm{~nm}<\Phi_{\mathrm{c}}<80 \mathrm{~nm}\right)$ above which they were not observed anymore. The true question now is: do NPs induce any bactericidal effect? 
a)

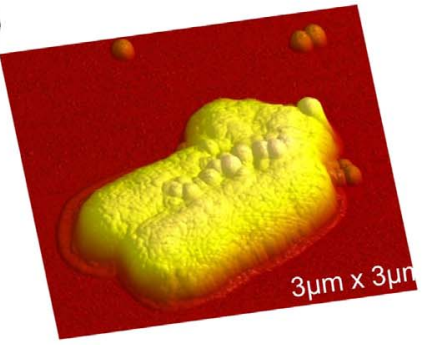

b)

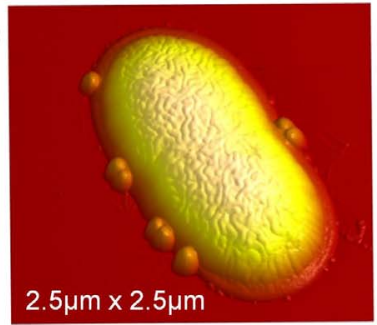

c)

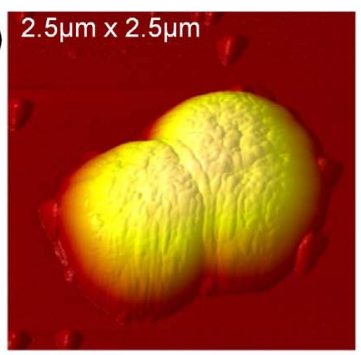

d)

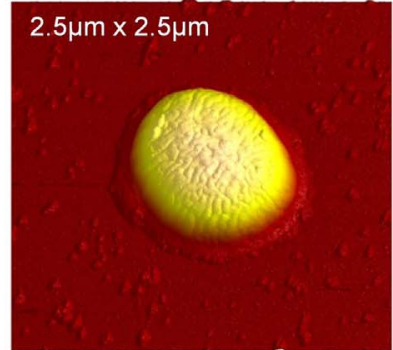

e)

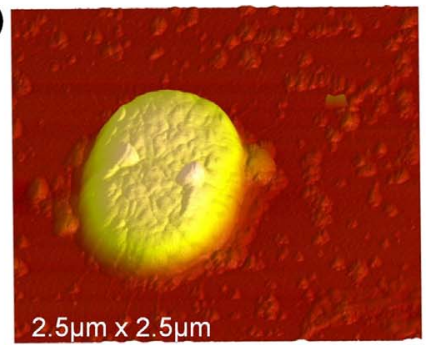

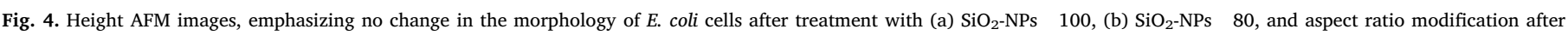
treatment with (c) $\mathrm{SiO}_{2}$-NPs 50 , (d) $\mathrm{SiO}_{2}$-NPs 10 and (e) $\mathrm{SiO}_{2}$-NPs 4 .

\subsection{Bactericidal effect of $\mathrm{SiO}_{2} \mathrm{NPs}^{-}$}

\subsubsection{NPs size < critical diameter $\Phi_{c}$}

Besides membrane degradations, the incubation of $E$. coli cells with $\mathrm{SiO}_{2} \mathrm{NPs}^{-}$4, 10 and 50 resulted, in some cases, in the collapse of $E$. coli cells. It is either partial, resulting in a drastic decrease of the bacteria height, or total, and bacteria were drained from their cellular contents and no more exhibited well organized membrane structure (Fig. 8a,b). Moreover, debris were observed on the mica substrate in the vicinity of bacteria aggregates exposed to $\mathrm{SiO}_{2} \mathrm{NPs}^{-} 4$ (Fig. 8c). Such fibrous materials, already observed as the result of cell surface perturbation [51], are indicative of cellular leakages. They can also correspond to

membrane components such as LPS aggregates being expelled due to the stress induced by such NPs.

\subsubsection{NPs size $>$ critical diameter $\Phi_{c}$}

$\mathrm{SiO}_{2} \mathrm{NPs}^{-} 80$ and 100 did not lead to any of these phenomena. In particular, E. coli cells suffered from no leakage of their intracellular compounds.

\section{6. $\mathrm{SiO}_{2} \mathrm{NPs}$ charge effect on $\mathrm{E}$. coli cells}

To decorrelate between size and charge effects on the interaction between $\mathrm{SiO}_{2} \mathrm{NPs}$ and $E$. coli, the influence of $\mathrm{SiO}_{2} \mathrm{NPs}^{+} 100\left(>\Phi_{\mathrm{c}}\right)$ is
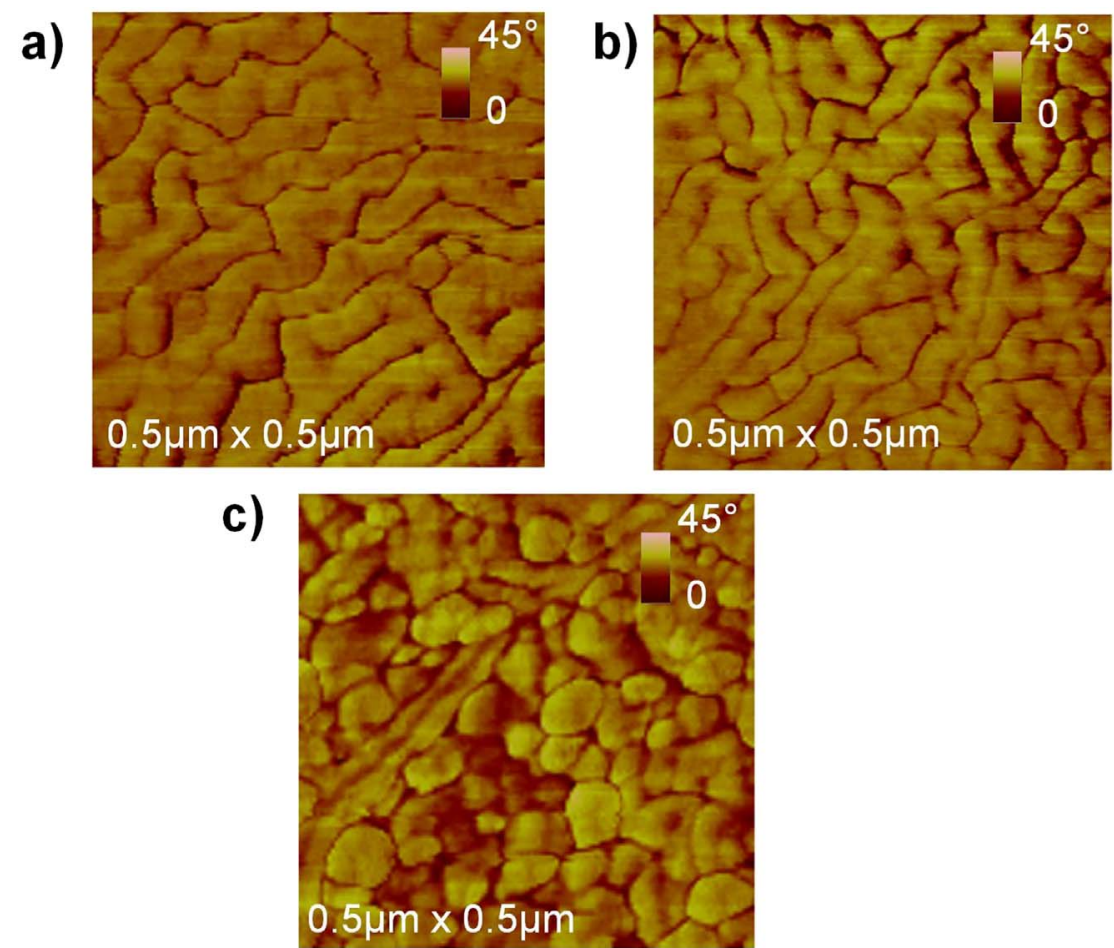

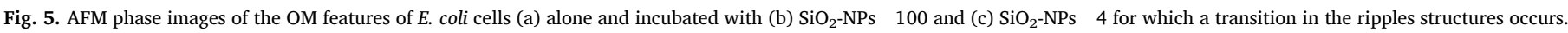


a)
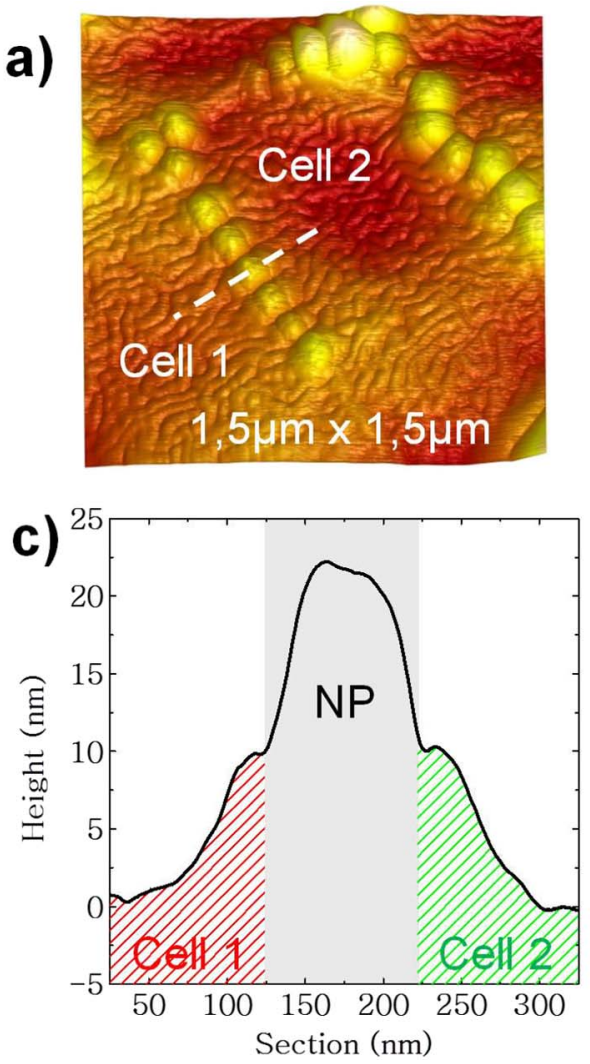

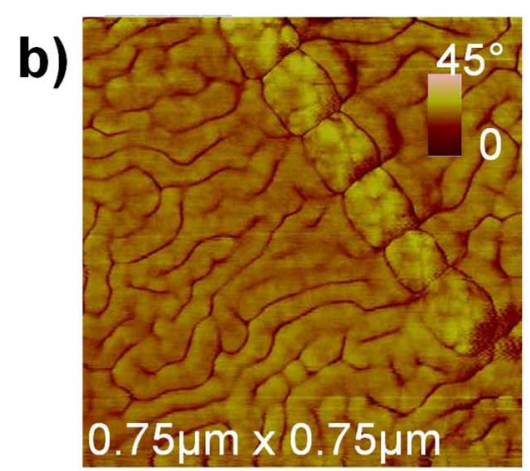

d)

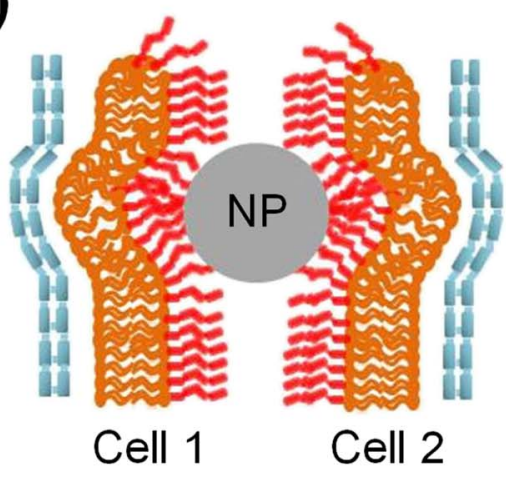

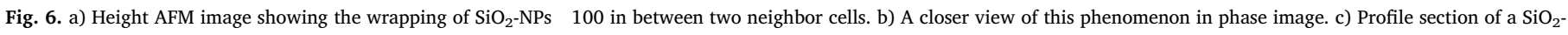
NPs 100 showed by the dashed line in (a). d) Proposed scheme of the OM deformation, leading to the formation of a "cocoon" around the NP.

now investigated.

$\mathrm{SiO}_{2} \mathrm{NPs}^{+} 100$ did not affect the CFUs, as for $\mathrm{SiO}_{2} \mathrm{NPs}^{-} 100$. However, AFM observations emphasized the aggregation between such positive NPs and E. coli. Indeed, unlike $\mathrm{SiO}_{2} \mathrm{NPs}^{-} 100, \mathrm{SiO}_{2} \mathrm{NPs}^{+} 100$ tended to exclusively accumulate and stick to, around and on bacteria, none being observed as free isolated or aggregated particles on the substrate (compare Fig. 3 and Fig. 9a). This emphasizes the privileged electrostatic affinity between $\mathrm{SiO}_{2} \mathrm{NPs}^{+}$and the negatively charged surface of $E$. coli, as confirmed by zeta potential measurements.

Furthermore, modifying the charge of $\mathrm{SiO}_{2} \mathrm{NPs}_{100}$ did not induce any change in E. coli rod shape morphology (Fig. 9b) nor in its OM ripples structure (Fig. 9c). However, unlike $\mathrm{SiO}_{2} \mathrm{NPs}^{-} 100$ which did not lead to any membrane degradations, $\mathrm{SiO}_{2} \mathrm{NPs}^{+} 100$ induced drastic damages including the formation of (i) extra membrane aggre gates and (ii) membrane invaginations. In the first case, aggregates with heights ranging from 4 to $15 \mathrm{~nm}$ surrounded cells (Fig. 10a b). In the second case, pore like lesions, similar to those observed with $\mathrm{SiO}_{2} \mathrm{NPs}^{-}$ smaller than $\Phi_{c}$, exhibited a depth of few tens of nanometer, which are not correlated to the NP size (Fig. 10c d).

\section{Discussion}

This work is the first study of exposure to NPs of the strain E. coli MRE 162, which was used, during the 70's, for military purposes. Although thought to be inoffensive, these $E$. coli were reported to cause diseases in highly susceptible individuals. This emphasizes the necessity of investigating on proper antibacterial agents (harmless for human cells) such as NPs, for commonly found bacteria like $E$. coli.

Former studies on the toxicity of $\mathrm{SiO}_{2} \mathrm{NPs}$ present contradictory results not only because of different methodologies but also because they do not necessarily address the same size nor the same surface state of $\mathrm{SiO}_{2} \mathrm{NPs}$, without explicitly mentioning these parameters in some cases. It is thus difficult to compare these results and to potentially demonstrate a size and charge effect tendency. In addition, despite a well known dose dependent cytotoxicity of antibacterial agents such as NPs [52], these studies differ in terms of concentration: E. coli growth inhibition was reported for a dose exposure of $2.0 \mathrm{~g} / \mathrm{L}[38,53]$ while, in another study, a concentration as low as $0.2 \mathrm{~g} / \mathrm{L}$ was inefficient [54].

Consequently, we undertook a systematic approach of this issue. We report herein (i) the potential antibacterial activity of $\mathrm{SiO}_{2} \mathrm{NPs}^{-}$, with diameters varying from 4 to $100 \mathrm{~nm}$, and (ii) the influence of the

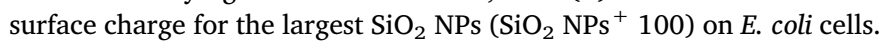
Based on previous studies and submitted to AFM observation conditions (to correctly visualize both NPs and bacteria), toxicity tests were performed, under static conditions, after a $2 \mathrm{~h}$ incubation with NPs at a concentration of $0.1 \mathrm{~g} / \mathrm{L}$. Their toxicity was rationalized with regards to their size and charge effects.

Viability experiments revealed the existence of a NP size threshold, $50 \mathrm{~nm}<\Phi_{\mathrm{c}}<80 \mathrm{~nm}$. Above $\Phi_{\mathrm{c}}, \mathrm{SiO}_{2} \mathrm{NPs}^{-}$had no influence on CFUs nor on the organization of $E$. coli population. Below $\Phi_{c}, \mathrm{SiO}_{2}$ $\mathrm{NPs}^{-}$induced an increase in CFUs associated to the easier separation of the initial cell clusters. This phenomenon is not due to an improved ability of cells to divide but rather to the capacity of these $\mathrm{SiO}_{2} \mathrm{NPs}^{-}$, despite their negative charge, to interact with the LPS layer of the bacteria OM, probably through hydrogen bonding with the LPS hydroxyl groups. These interactions are likely stronger than cell cell ones as they could break down cells clusters. To the best of our knowledge, this splitting effect has never been reported nor correlated to a size dependent action of NPs on cells. Former studies only described the size effect of NPs in terms of CFUs decrease always related to viability losses: for instance, the antibacterial activity decreases with an increase of the size of $\mathrm{TiO}_{2}$ [31] and Ag [55] NPs. We, here, emphasized that CFUs counting is definitely insufficient by itself to probe toxicity phenomena since it reflects a competition between (i) the number of isolated cells, increased by splitting effects and (ii) the number of viable cells, decreased by potential antibacterial 
a)

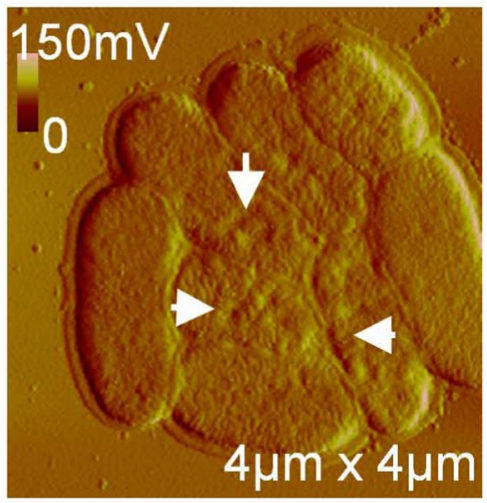

b)

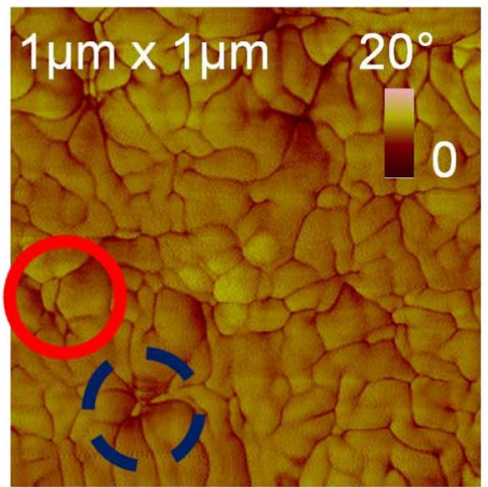

c)

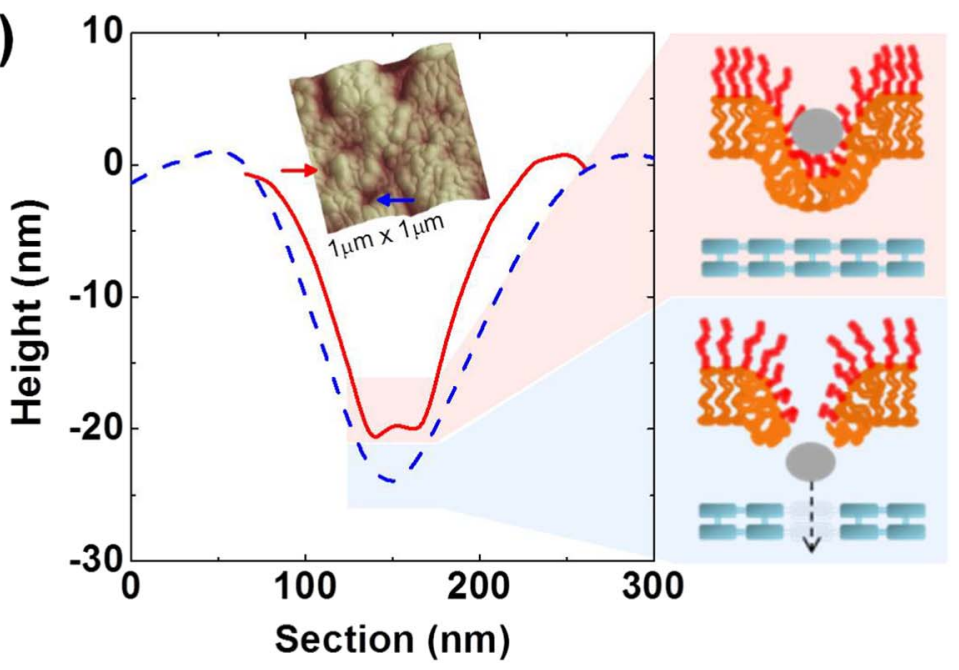

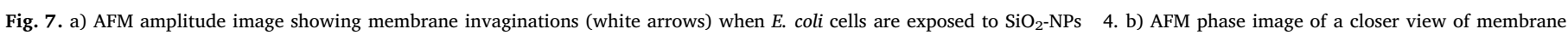

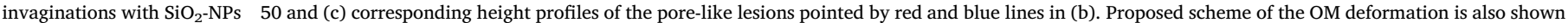
in (c). (For interpretation of the references to colour in this figure legend, the reader is referred to the web version of this article.)
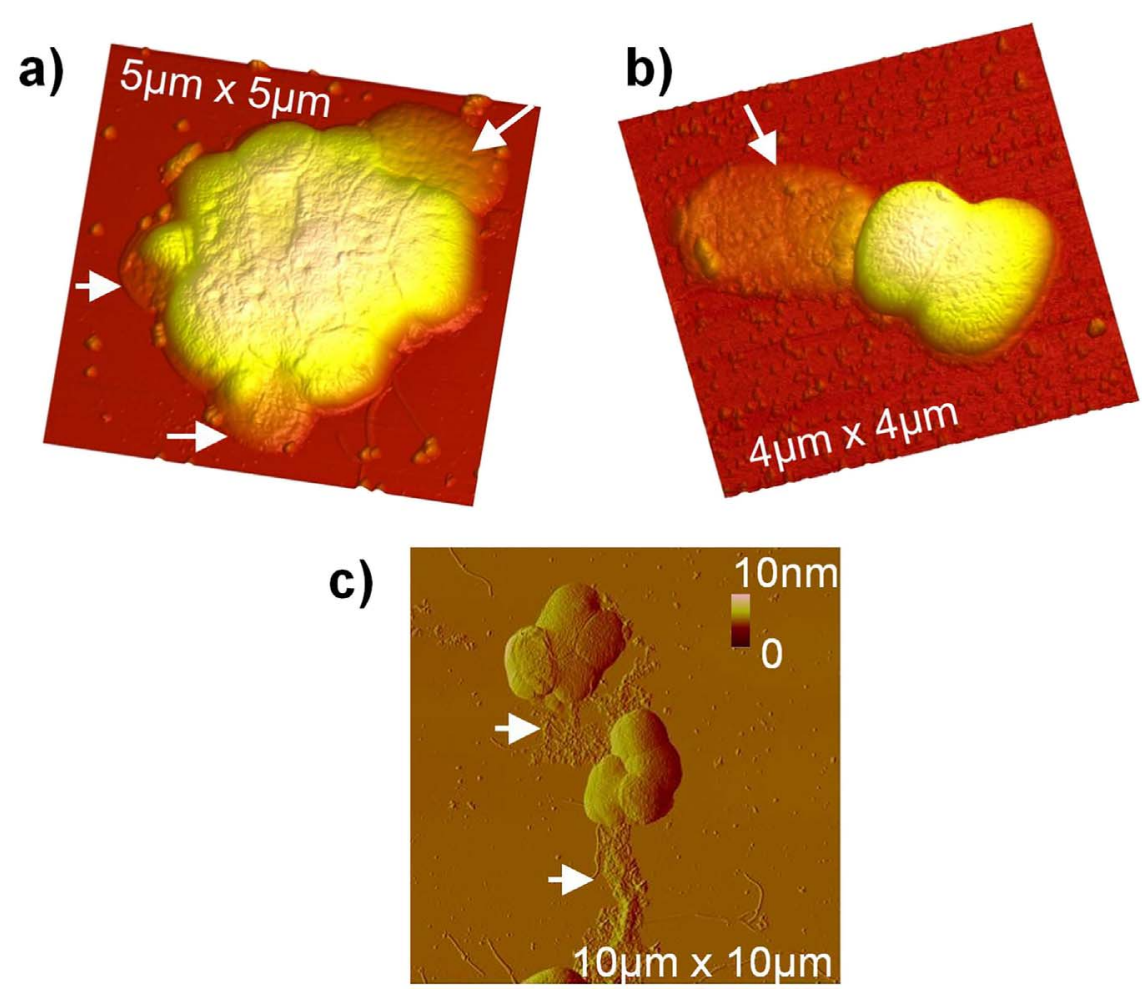

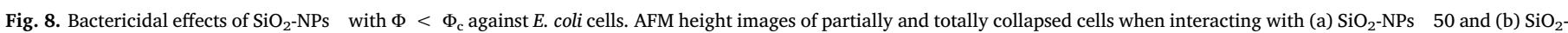
NPs 10. c) AFM amplitude image showing debris due to bacteria lysis on the substrate when $E$. coli cells interact with $\mathrm{SiO}_{2}-\mathrm{NPs} 4$. Damages are indicated by full arrows. 

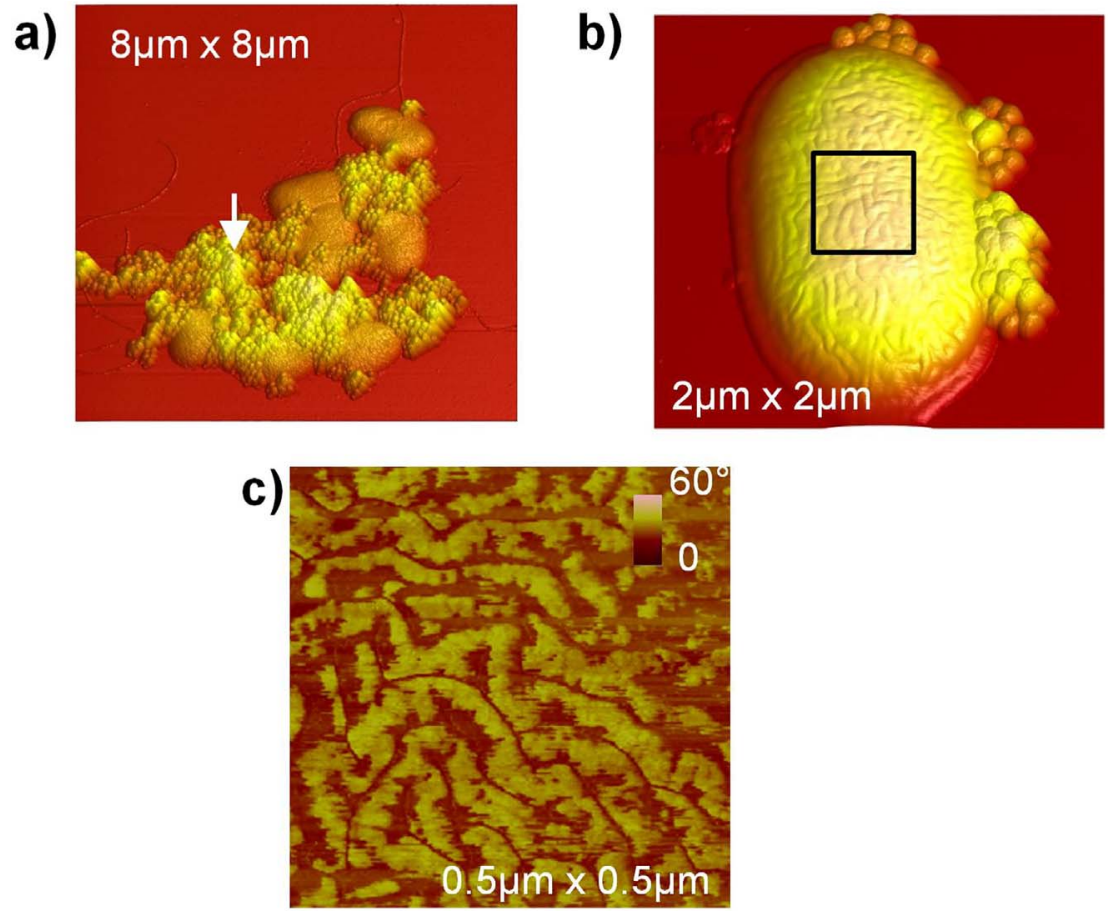

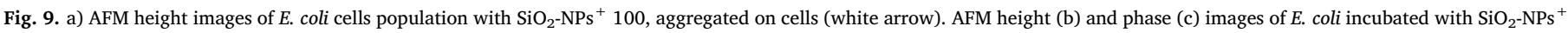
100 showing its unchanged morphology and OM structure.

activity (Fig. 2c).

From this point of view, AFM proved to provide complementary and necessary information, at the cellular level, on the NPs size dependent antibacterial activity. Firstly, it emphasized the particular ultrastruc ture present on healthy E.coli's surface. This "brain like" organization, here called ripples, is attributed to the conformation of LPS molecules in the OM [56]. Then, AFM observations confirmed, at the cellular level, the existence of a NPs size threshold, $50 \mathrm{~nm}<\Phi_{\mathrm{c}}<80 \mathrm{~nm}$. On the one hand, $\mathrm{SiO}_{2} \mathrm{NPs}^{-}$larger than $\Phi_{\mathrm{c}}$ do not induce any particular damage on the overall morphology of $E$. coli nor on its OM structure.
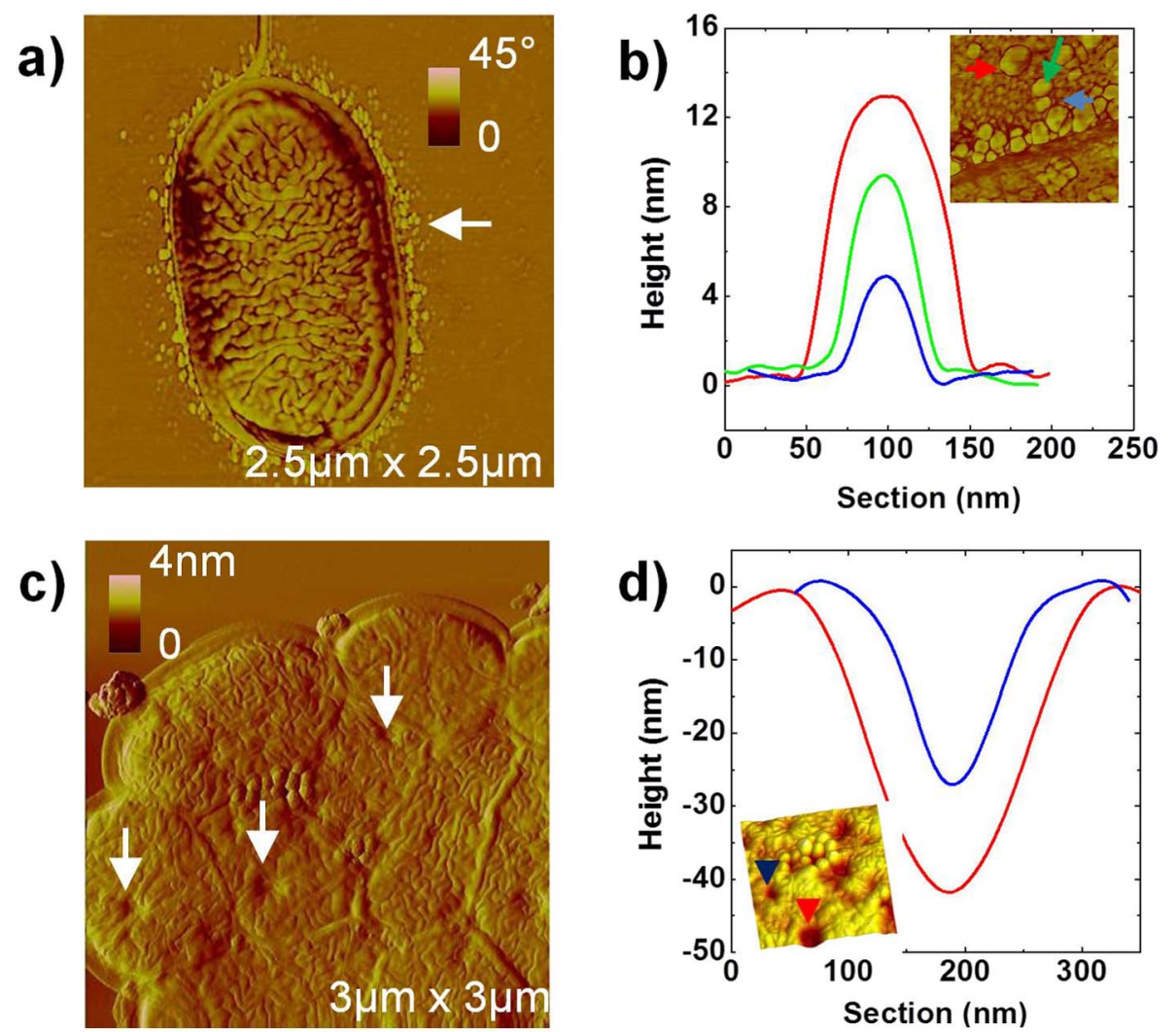

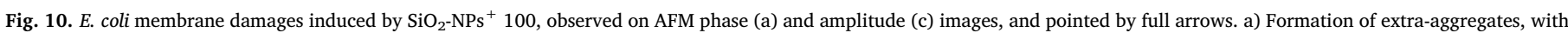
(b) height profiles representative of diverse aggregates. c) Formation of membrane invaginations with (d) height profiles representative of diverse invaginations. 
Noteworthy is the partial wrapping observed for these NPs trapped in between cells (Fig. 6c). A balance between adhesion and free energies is here assumed for the NP not to translocate through cells, as already observed by Livadaru and Kovalenko in a statistical mechanical approach of membrane invaginations [57]. On the other hand, $\mathrm{SiO}_{2}$ $\mathrm{NPs}^{-}$smaller than $\Phi_{\mathrm{c}}$ strongly disturb $E$. coli cells. The pore like lesions observed are deep enough, as compared to the OM thickness (around $8 \mathrm{~nm}$ ), for these $\mathrm{SiO}_{2} \mathrm{NPs}^{-}$to (i) disrupt this $\mathrm{OM}$ and induce its invagination or piercing and even to (ii) damage the underlying peptidoglycan layer (Fig. 7c) which is involved not only in cell division processes but also in the preservation of the cell wall uniformity and cell shape. Permeabilization of this layer is also reinforced by the more spherical shape of bacteria. Such invaginations were reported in antibiotic (penicillin and amoxicillin) treatment of E. coli, interfering with enzymes involved in the peptidoglycan synthesis [58]. In addition, $\mathrm{SiO}_{2} \mathrm{NPs}^{-}$smaller than $\Phi_{\mathrm{c}}$ induce a reorganization in E. coli's OM structure from a ripples pattern to more compact and rounded aggregates, typical of weakened bacteria [56]. This transition might arise from (i) the spatial reorganization of the LPS molecules from a ripples structure to an aggregated one or (ii) from the transition in their molecular conformation from an extended to a more condensed one. In both cases, this transition is in agreement with the polymer like behavior [59] of LPS when undergoing an external pressure [60]. It is likely due to small $\mathrm{SiO}_{2} \mathrm{NPs}^{-}$interfering in the core of the $\mathrm{OM}$ and forcing the molecules to reorganize as compression does in the case of Langmuir monolayer experiments (Fig. S3) [60]. It is not excluded either that a strong hydrogen bonding between these $\mathrm{SiO}_{2} \mathrm{NPs}^{-}$and the multiple hydroxyls groups of LPS molecules does play a role in this disorganization. It induces a break in the crystalline organization of LPS and thus the loss of the brain like structure, this process being much easier with smaller NPs. At some point, especially for the 4 and $10 \mathrm{~nm}$ sizes, NPs might penetrate in the grooves of the LPS layer. Finally, observed lysis and consequent leakage of intracellular components, could occur through these pore like lesions or through the complete and direct destruction of the cell inner membrane. Indeed, cell lysis suggests that, when $\mathrm{SiO}_{2} \mathrm{NPs}^{-}$reach the peptidoglycan layer, they are inter nalized and translocated, and reach the inner membrane leading to potential toxicity. For cells remaining alive (healthy appearance), $\mathrm{SiO}_{2}$ $\mathrm{NPs}^{-}$might be trapped outside the peptidoglycan layer protecting the inner membrane and thus the cell integrity. Considering these damages, $\mathrm{SiO}_{2} \mathrm{NPs}^{-}$smaller than $\Phi_{\mathrm{c}}$ have similar effects as some antimicrobial peptides following the "carpet model" $[61,62]$.

Independently of their sizes, the positive surface charge of $\mathrm{SiO}_{2} \mathrm{NPs}$ generates strong attractive electrostatic interactions with negatively charged $E$. coli bacteria. This affinity appears to favor antibacterial activity of $\mathrm{SiO}_{2} \mathrm{NPs}$. Indeed, $\mathrm{SiO}_{2} \mathrm{NPs}^{+} 100$ lead to drastic membrane invaginations, similar to those observed with $\mathrm{SiO}_{2} \mathrm{NPs}^{-}$smaller than $\Phi_{\mathrm{c}}$ and blebbing phenomenon. As $\Phi>\Phi_{\mathrm{c}}$, the size influence is, here, ruled out, implying a different mechanism for such damages, probably a consequence of the electrostatic field induced by $\mathrm{SiO}_{2} \mathrm{NPs}^{+}$. This surface charge dependent toxicity confirms previous studies on silver NPs either bare or coated $[30,63]$.

\section{Conclusion}

We have demonstrated the size and charge dependent toxicity of $\mathrm{SiO}_{2} \mathrm{NPs}$ towards $E$. coli bacteria, through a systematic approach. Cells were exposed to commercial and home made $\mathrm{SiO}_{2} \mathrm{NPs}$ with different sizes $(4,10,50,80$ and $100 \mathrm{~nm})$, either bare $\left(\mathrm{SiO}_{2} \mathrm{NPs}^{-}\right)$or functio nalized $\left(\mathrm{SiO}_{2} \mathrm{NPs}^{+}\right)$and their toxicity emphasized by viability tests and AFM observations. We demonstrated the existence of a critical dia meter, $50 \mathrm{~nm}<\Phi_{\mathrm{c}}<80 \mathrm{~nm}$, under which cell damages were ob served: OM invaginations and reorganization (from ripples for healthy cells to aggregates for weakened and damaged ones). We reported, for the first time, the splitting effects of these $\mathrm{SiO}_{2} \mathrm{NPs}^{-}$on cells and its potential interaction with toxicity phenomena. We also showed that
$\mathrm{SiO}_{2}$ NPs larger than $\Phi_{\mathrm{c}}$ did not affect $E$. coli cells unless they were positively charged, $\mathrm{SiO}_{2} \mathrm{NPs}^{+} 100$ inducing similar damage as the smallest negative $\mathrm{SiO}_{2} \mathrm{NPs}^{-}$. Finally, the particular membrane reorga nization emphasized the importance of LPS structure in $E$. coli in the resistance to external stress and the need for further studies on its nanomechanical properties and its interaction with NPs.

\section{Materials and methods}

For convenient reasons, we will use thereafter short names for all used NPs. For instance, negatively charged silica NPs of $4 \mathrm{~nm}$ in diameter will stand as $\mathrm{SiO}_{2} \mathrm{NPs}^{-}$4. Similar expressions will be used for all NPs.

\subsection{Materials}

Commercial $\mathrm{SiO}_{2} \mathrm{NPs}^{-}$10, 50 and 100 were purchased from Biovalley (Marne la Vallée, France) and $\mathrm{SiO}_{2} \mathrm{NPs}^{-} 4$ from Alfa Aesar (Schiltigheim, France). Gram negative E. coli bacteria (MRE 162 strain) were a kind gift from the Centre d'Etudes du Bouchet, DGA (Direction Générale de l'Armement, France). Mica, purchased from Electron Microscopy Sciences (Hatfield, United States), was used as support for all AFM measurements. Luria Broth (LB) medium was used as nutritive medium and purchased from Fisher Scientific (Waltham, Massachusetts, United States). L Arginine and tetraethylorthosilicate (TEOS), used for silica seeds synthesis, were purchased from Sigma Aldrich (Saint Louis, Missouri, United States) as well as aminopropyl triethoxysilane (APS), used for NPs functionalization. Ethanol and ammonium hydroxide, used for $\mathrm{SiO}_{2} \mathrm{NPs}$ growth, were also purchased from Sigma Aldrich. Millipore ultrapure water ( $\mathrm{pH} 5.5$, resistivity $>18.2 \mathrm{M} \Omega \mathrm{cm}$ ) was used for NPs cleaning and bacteria suspensions preparation.

\subsection{Preparation and characterization of $\mathrm{SiO}_{2} \mathrm{NPs}$ solutions}

To obtain a large range of NPs sizes, we used both commercial and home synthesized $\mathrm{SiO}_{2} \mathrm{NPs}$. Home synthesis was also used to functio nalize the negatively charged $\mathrm{NPs}\left(\mathrm{SiO}_{2} \mathrm{NPs}^{-}\right)$and get a positive surface charge $\left(\mathrm{SiO}_{2} \mathrm{NPs}^{+}\right)$.

Commercial $\mathrm{SiO}_{2} \mathrm{NPs}^{-}$were centrifuged three times at $9000 \mathrm{~g}$ for $45 \mathrm{~min}$ (20 min were enough for $\mathrm{SiO}_{2} \mathrm{NPs}^{-} 100$ ), cleaned and redis persed in ultrapure water. $\mathrm{SiO}_{2} \mathrm{NPs}^{-}$were then placed in a sonication bath for approximately $1 \mathrm{~h}$ to ensure minimal aggregation in the solution.

Synthesis of home made $\mathrm{SiO}_{2} \mathrm{NPs}^{-}$was carried out following synthesis developed by Hartlen et al. [64]. The first step consisted in synthesizing $\mathrm{SiO}_{2}$ seeds. $100 \mathrm{~mL}$ of a $6 \mathrm{mM} \mathrm{L}$ arginine water solution was introduced in a vial at $60{ }^{\circ} \mathrm{C}$, under magnetic stirring $(150 \mathrm{rpm})$. After temperature stabilisation, $10 \mathrm{~mL}$ of TEOS were slowly added so as to respect the interface. Seeds of about $30 \mathrm{~nm}$ in diameter were obtained after complete consumption of TEOS. The second step consisted in the growth of these seeds. Typically, $10 \mathrm{~mL}$ of $\mathrm{SiO}_{2}$ seeds were introduced in a mixture of $455 \mathrm{~mL}$ of ethanol and $35 \mathrm{~mL}$ of ammonium hydroxide in water solution $\left(\left[\mathrm{NH}_{3}\right]=1 \mathrm{M}\right)$, under stirring (700 rpm). TEOS was then introduced in the amount calculated to get the targeted diameter, at a rate of $0.5 \mathrm{~mL} / \mathrm{h}$ [65]. Surface modification was performed by adding APS (six equivalents assuming a rate of 2 $3 \mu \mathrm{mol} / \mathrm{m}^{2}$ of active $\mathrm{OH}$ groups at the surface of the silica particles) to the $\mathrm{SiO}_{2} \mathrm{NPs}^{-}$solution; the mixture was then stirred for $48 \mathrm{~h}$ in a water bath at room temperature, and then for $2 \mathrm{~h}$ at $100{ }^{\circ} \mathrm{C}$. Final $\mathrm{SiO}_{2} \mathrm{NPs}^{+}$ were washed using ultrapure water and ethanol and 3 cycles of centrifugation (13,000 rpm for $20 \mathrm{~min}$.)

Dynamic Light Scattering (DLS) experiments were carried out on a Malvern Zetasizer Nano ZS setup (Orsay, France) to determine the size and polydispersity of NPs. This method provides information on both the hydrodynamic diameter of the $\mathrm{SiO}_{2} \mathrm{NPs}$ in solution and their 
polydispersity. Transmission Electron Microscopy (TEM) with a JEOL JEM 1400 Plus and AFM observations were also used to investigate not only the size and morphology of $\mathrm{SiO}_{2} \mathrm{NPs}$ but also their organization on a substrate. Consequently, while TEM images give the silica NPs diameter (i.e. its core), DLS measurements give the hydrodynamic diameter of the NPs including the first sphere of coordination of the solvent. Zeta potential measurements were carried out on a Wallis Zeta potential analyzer from Cordouan (Pessac, France). For these three characterizations, $\mathrm{SiO}_{2} \mathrm{NPs}$ were suspended in ultrapure water to obtain a final concentration of $0.1 \mathrm{~g} / \mathrm{L}$ and sonicated before any experiments.

\subsection{Bactericidal susceptibility test}

A fresh $E$. coli culture was obtained by inoculating $50 \mathrm{~mL}$ of $\mathrm{LB}$ medium with $250 \mu \mathrm{L}$ of an overnight culture. The bacterial growth was followed by measuring the optical density (OD) at $600 \mathrm{~nm}$, using a Helios gamma spectrophotometer (Thermo Scientific), until it reached 0.60 . The suspension was further centrifuged $(8000 \mathrm{rpm}$ for $10 \mathrm{~min}$. at $4{ }^{\circ} \mathrm{C}$ ), and the cell pellet was re diluted in ultrapure water to obtain an OD of 0.01 . Finally, NPs were introduced in the suspension at the desired concentration ( $1 \mathrm{~g} / \mathrm{L})$ and left to interact for $2 \mathrm{~h}$, under static conditions, at room temperature. At the end of the incubation period, ten fold serial dilutions in ultrapure and sterile water of the suspensions were made and $100 \mu \mathrm{L}$ of each dilution were spread onto LB agar plates. Bactericidal effects were evaluated by counting the number of colonies (CFU for colony forming units) developed on plates after $16 \mathrm{~h}$ at $37^{\circ} \mathrm{C}$. Average values of three independent experiments are reported there after.

\subsection{Dark field microscopy observations}

For dark field microscopy observations, E. coli cells were grown in LB medium until the culture reached an $\mathrm{OD}=0.60$ at $600 \mathrm{~nm}$. The bacterial cells were centrifuged $\left(8000 \mathrm{rpm}\right.$ for $10 \mathrm{~min}$ at $4{ }^{\circ} \mathrm{C}$ ) and re suspended in ultrapure, sterile water to obtain an OD $=0.60$ at $600 \mathrm{~nm}$ before being incubated in the presence of the different NPs at $1 \mathrm{~g} / \mathrm{L}$ for $2 \mathrm{~h}$ at room temperature under static conditions. A microscope Eclipse $\mathrm{Ni}$ (Nikon) equipped with a dark field condenser (oil 1.4631 .20 ) and an objective Achromat $40 \times / 0.65$ both from Nikon was used for dark field image acquisition. Images were acquired with a Nikon DS Qi1Mc camera and NIS Elements software. Representative images are provided thereafter.

\subsection{Preparation of NPS E. coli suspensions for AFM experiments}

E. coli cells were grown on LB agar plates and incubated for $16 \mathrm{~h}$ at $37^{\circ} \mathrm{C}$. After scraping, bacteria were suspended in ultrapure water and their concentration was adjusted to $10^{6}$ cells $/ \mathrm{mL}$. An equivalent volume of $E$. coli cells and $\mathrm{SiO}_{2}$ NPs suspensions at a concentration of $0.1 \mathrm{~g} / \mathrm{L}$, were mixed and gently manually shaken (4 times every $20 \mathrm{~min}$ ), then left to interact at room temperature for $2 \mathrm{~h}$. Five microliters of each mixed suspension was deposited on freshly cleaved mica, left to dry in a desiccator and imaged by AFM the following day.

\subsection{AFM experiments}

Briefly, AFM consists of a cantilever with a nanoprobe at its end which, along with a piezo scanner, scans the sample surface. In close proximity, small (attractive and repulsive) forces between the probe and the surface lead to the deflection of the cantilever, which is recorded. This technique gives information on morphological and mechanical properties (adhesion, visco elasticity) of a surface, at the nanometer level. In this work, AFM experiments were carried out using a Bioscope II mounted on an IX71 Olympus inverted optical microscope operating with the NanoScope V controller and also with a Multimode
AFM (Veeco Brucker, Santa Barbara, USA).

Though, imaging in liquid is preferred for cells hydration, air conditions were privileged for a better resolution $[42,66]$ (due to tip bacteria interactions), notably on the topographical and nanomechani cal contrasts on the surface structure of bacteria. It also allows to work in dynamic tapping mode and, consequently, to take advantage of the harmonic oscillator behavior of the cantilever. Thus, very small forces were used, preventing any damages to the samples. Tapping mode images were obtained with commercial cantilevers with a spring constant around $40 \mathrm{~N} / \mathrm{m}$, at a scan rate of 0.5 to $1.0 \mathrm{~Hz}$ and with a resolution of $512 \times 512$ pixels. For each experiment, height, amplitude and trace phase images were recorded. Height images stand for topographical relief of the sample. Phase images show the phase difference between exciting and response signals, arising from the sample nanomechanical properties. Thus, they are linked to (i) dissipa tion processes between the tip and the sample and (ii) surface hardness. For instance, a homogenous surface (composition and organization) will not show any significant contrast in phase. Amplitude images (error signal) provide additional information on the topography and morphology of very fine details which might be saturated in height images.

Hereafter, samples were observed, in tapping mode, in the day following their preparation to prevent any interference, like ageing of $E$. coli biofilm [56], with the potential damage caused by $\mathrm{SiO}_{2} \mathrm{NPs}$. Different areas were systematically scanned and images shown there after are representative of the cells in a given set of colonies and of all the tested samples.

\section{Acknowledgments}

The authors thank the Région Aquitaine and CNRS (France) for supporting this work through the equipment of the NanoSpectroImagerie (NSI LOMA) platform used in this work (CPER COLA2). They are grateful to the Direction Générale de l'Armement (DGA, Ministère de la Défense France, grant number : 2014017) and the Région Aquitaine (France) for their financial support through the Ph.D. grant of M. Mathelié Guinlet. Finally, authors thank NSI LOMA plat form for technical help and J.P Chapel for its helpful advises and discussions about DLS measurements.

\section{Appendix A. Supplementary data}

Supplementary data to this article can be found online at http://dx. doi.org/10.1016/j.cis.2017.04.012.

\section{References}

[1] Srivastava V, Gusain D, Sharma YC. Critical review on the toxicity of some widely used engineered nanoparticles. Ind Eng Chem Res 2015;54:6209-33. http://dx.doi. org/10.1021/acs.iecr.5b01610.

[2] Buzea C, Pacheco II, Robbie K. Nanomaterials and nanoparticles: sources and toxicity. Biointerphases 2007;2:MR17. http://dx.doi.org/10.1116/1.2815690.

[3] Kahru A, Ivask A. Mapping the dawn of nanoecotoxicological research. Acc Chem Res 2013;46:823-33. http://dx.doi.org/10.1021/ar3000212.

[4] Nel A, Xia T, Mädler L, Li N. Toxic potential of materials at the nanolevel. Science 2006;311:622-7.

[5] Oberdörster G, Oberdörster E, Oberdörster J. Nanotoxicology: an emerging discipline evolving from studies of ultrafine particles. Environ Health Perspect 2005;113:823-39. http://dx.doi.org/10.1289/ehp.7339.

[6] Lewinski N, Colvin V, Drezek R. Cytotoxicity of nanoparticles. Small 2008;4:26-49. http://dx.doi.org/10.1002/smll.200700595.

[7] Djurišić AB, Leung YH, Ng A, Xu XY, Lee PK, Degger N. Toxicity of metal oxide nanoparticles: mechanisms, characterization, and avoiding experimental artefacts. Small 2015;11:26-44.

[8] Beddoes CM, Case CP, Briscoe WH. Understanding nanoparticle cellular entry: a physicochemical perspective. Adv Colloid Interf Sci 2015;218:48-68. http://dx.doi. org/10.1016/j.cis.2015.01.007.

[9] Tolaymat TM, El Badawy AM, Genaidy A, Scheckel KG, Luxton TP, Suidan M. An evidence-based environmental perspective of manufactured silver nanoparticle in syntheses and applications: a systematic review and critical appraisal of peerreviewed scientific papers. Sci Total Environ 2010;408:999-1006. http://dx.doi. 
org/10.1016/j.scitotenv.2009.11.003.

[10] Farokhzad OC, Langer R. Impact of nanotechnology on drug delivery. ACS Nano 2009;3:16-20. http://dx.doi.org/10.1021/nn900002m.

[11] Duncan R, Gaspar R. Nanomedicine(s) under the microscope. Mol Pharm 2011;8:2101-41. http://dx.doi.org/10.1021/mp200394t.

[12] Das M, Duan W, Sahoo SK. Multifunctional nanoparticle-EpCAM aptamer bioconjugates: a paradigm for targeted drug delivery and imaging in cancer therapy. Nanomedicine Nanotechnol Biol Med 2015;11:379-89. http://dx.doi.org/10.1016/ j.nano.2014.09.002.

[13] Dastjerdi R, Montazer M. A review on the application of inorganic nano-structured materials in the modification of textiles: focus on anti-microbial properties. Colloids Surf B Biointerfaces 2010;79:5-18. http://dx.doi.org/10.1016/j.colsurfb.2010.03. 029.

[14] Yetisen AK, Qu H, Manbachi A, Butt H, Dokmeci MR, Hinestroza JP, et al. Nanotechnology in textiles. ACS Nano 2016. http://dx.doi.org/10.1021/acsnano. 5 b08176.

[15] Oliveira ON, Iost RM, Siqueira JR, Crespilho FN, Caseli L. Nanomaterials for diagnosis: challenges and applications in smart devices based on molecular recognition. ACS Appl Mater Interfaces 2014;6:14745-66. http://dx.doi.org/10. 1021/am5015056.

[16] Sanvicens N, Pastells C, Pascual N, Marco M-P. Nanoparticle-based biosensors for detection of pathogenic bacteria. TrAC Trends Anal Chem 2009;28:1243-52. http://dx.doi.org/10.1016/j.trac.2009.08.002.

[17] Nikaido $\mathrm{H}$. Molecular basis of bacterial outer membrane permeability revisited. Microbiol Mol Biol Rev 2003;67:593-656. http://dx.doi.org/10.1128/MMBR.67.4. 593-656.2003.

[18] Spratt BG. Independent review of the possible health hazards of the large-scale release of bacteria during the dorset defence trials n.d.

[19] Kaweeteerawat C, Ivask A, Liu R, Zhang H, Chang CH, Low-Kam C, et al. Toxicity of metal oxide nanoparticles in Escherichia coli correlates with conduction band and hydration energies. Environ Sci Technol 2015;49:1105-12. http://dx.doi.org/10. 1021/es504259s.

[20] Lee C, Kim JY, Lee WI, Nelson KL, Yoon J, Sedlak DL. Bactericidal effect of zerovalent iron nanoparticles on Escherichia coli. Environ Sci Technol 2008;42:4927-33. http://dx.doi.org/10.1021/es800408u.

[21] Yoon K-Y, Hoon Byeon J, Park J-H, Hwang J. Susceptibility constants of Escherichia coli and Bacillus subtilis to silver and copper nanoparticles. Sci Total Environ 2007;373:572-5. http://dx.doi.org/10.1016/j.scitotenv.2006.11.007.

[22] Sahoo P, Murthy PS, Dhara S, Venugopalan VP, Das A, Tyagi AK. Probing the cellular damage in bacteria induced by GaN nanoparticles using confocal laser Raman spectroscopy. J Nanopart Res 2013;15. http://dx.doi.org/10.1007/s11051013-1841-9.

[23] Singh G, Joyce EM, Beddow J, Mason TJ, et al. Evaluation of antibacterial activity of $\mathrm{ZnO}$ nanoparticles coated sonochemically onto textile fabrics. J Microbiol Biotechnol Food Sci 2012;2:106-20.

[29] Goodman CM, McCusker CD, Yilmaz T, Rotello VM. Toxicity of gold nanoparticles functionalized with cationic and anionic side chains. Bioconjug Chem 2004;15:897-900. http://dx.doi.org/10.1021/bc049951i.

[30] Silva T, Pokhrel LR, Dubey B, Tolaymat TM, Maier KJ, Liu X. Particle size, surface charge and concentration dependent ecotoxicity of three organo-coated silver nanoparticles: comparison between general linear model-predicted and observed toxicity. Sci Total Environ 2014;468-469:968-76. http://dx.doi.org/10.1016/j. scitotenv.2013.09.006.

[31] Simon-Deckers A, Loo S, Mayne-L'hermite M, Herlin-Boime N, Menguy N, Reynaud C, et al. Size-, composition-and shape-dependent toxicological impact of metal oxide nanoparticles and carbon nanotubes toward bacteria. Environ Sci Technol 2009;43:8423-9.

[32] Xiao X, Montaño GA, Edwards TL, Allen A, Achyuthan KE, Polsky R, et al. Surface charge dependent nanoparticle disruption and deposition of lipid bilayer assemblies. Langmuir 2012;28:17396-403. http://dx.doi.org/10.1021/la303300b.

[33] Roiter Y, Ornatska M, Rammohan AR, Balakrishnan J, Heine DR, Minko S. Interaction of lipid membrane with nanostructured surfaces. Langmuir 2009;25:6287-99. http://dx.doi.org/10.1021/la900119a.

[34] Tan W, Wang K, He X, Zhao XJ, Drake T, Wang L, et al. Bionanotechnology based on silica nanoparticles. Med Res Rev 2004;24:621-38. http://dx.doi.org/10.1002/ med.20003.

[35] Wang Y, Zhao Q, Han N, Bai L, Li J, Liu J, et al. Mesoporous silica nanoparticles in drug delivery and biomedical applications. Nanomedicine Nanotechnol Biol Med 2015;11:313-27. http://dx.doi.org/10.1016/j.nano.2014.09.014.

[36] Pham MT, Nguyen TV, Vu Thi TD, Nghiem Thi HL, Tong KT, Tran TT, et al. Synthesis, photophysical properties and application of dye doped water soluble silica-based nanoparticles to label bacteria E. coli O157:H7. Adv Nat Sci Nanosci Nanotechnol 2012;3:045013http://dx.doi.org/10.1088/2043-6262/3/4/045013.

[37] Liu T, Song X, Shen Y, Guo Z, Xue J, Wu H. Antibacterial mechanisms of silica/ polydopamine/silver nanoparticles against gram positive and gram negative bacteria. Micro Nano Lett 2014;9:210-4. http://dx.doi.org/10.1049/mnl.2014. 0014.

[38] Adams LK, Lyon DY, Alvarez PJJ. Comparative eco-toxicity of nanoscale $\mathrm{TiO}_{2}, \mathrm{SiO}_{2}$, and $\mathrm{ZnO}$ water suspensions. Water Res 2006;40:3527-32. http://dx.doi.org/10. 1016/j.watres.2006.08.004.

[39] Lewinski N, Colvin V, Drezek R. Cytotoxicity of nanoparticles. Small 2008;4:26-49. http://dx.doi.org/10.1002/smll.200700595.

[40] Brayner R, Ferrari-Iliou R, Brivois N, Djediat S, Benedetti MF, Fiévet F. Toxicological impact studies based on Escherichia coli bacteria in ultrafine $\mathrm{ZnO}$ nanoparticles colloidal medium. Nano Lett 2006;6:866-70. http://dx.doi.org/10. $1021 /$ nl052326h.
[41] Sondi I, Salopek-Sondi B. Silver nanoparticles as antimicrobial agent: a case study on $E$. coli as a model for Gram-negative bacteria. J Colloid Interface Sci 2004;275:177-82. http://dx.doi.org/10.1016/j.jcis.2004.02.012.

[42] Bolshakova AV, Kiselyova OI, Yaminsky IV. Microbial surfaces investigated using atomic force microscopy. Biotechnol Prog 2004;20:1615-22. http://dx.doi.org/10. 1021/bp049742c.

[43] Gaboriaud F, Dufrêne YF. Atomic force microscopy of microbial cells: application to nanomechanical properties, surface forces and molecular recognition forces. Colloids Surf B Biointerfaces 2007;54:10-9. http://dx.doi.org/10.1016/j.colsurfb. 2006.09.014.

[44] Muller DJ. AFM: a nanotool in membrane biology. Biochemistry (Mosc) 2008;47:7986-98. http://dx.doi.org/10.1021/bi800753x.

[45] Shang L, Nienhaus K, Nienhaus GU. Engineered nanoparticles interacting with cells: size matters. J Nanobiotechnol 2014;12:b26.

[46] Bannunah AM, Vllasaliu D, Lord J, Stolnik S. Mechanisms of nanoparticle internalization and transport across an intestinal epithelial cell model: effect of size and surface charge. Mol Pharm 2014;11:4363-73. http://dx.doi.org/10.1021/ mp500439c.

[47] Rozen Y, Belkin S. Survival of enteric bacteria in seawater. FEMS Microbiol Rev 2001;25:513. http://dx.doi.org/10.1111/j.1574-6976.2001.tb00589.x.

[48] Vital M, Hammes F, Egli T. Escherichia coli 0157 can grow in natural freshwater at low carbon concentrations. Environ Microbiol 2008;10:2387-96. http://dx.doi.org/ 10.1111/j.1462-2920.2008.01664.x.

[49] Blaustein RA, Pachepsky Y, Hill RL, Shelton DR, Whelan G. Escherichia coli survival in waters: temperature dependence. Water Res 2013;47:569-78. http://dx.doi.org/ 10.1016/j.watres.2012.10.027.

[50] Daniel RA, Errington J. Control of cell morphogenesis in bacteria: two distinct ways to make a rod-shaped cell. Cell 2003;113:767-76.

[51] Alves CS, Melo MN, Franquelim HG, Ferre R, Planas M, Feliu L, et al. Escherichia coli cell surface perturbation and disruption induced by antimicrobial peptides BP100 and pepR. J Biol Chem 2010;285:27536-44. http://dx.doi.org/10.1074/jbc.M110. 130955.

[52] Napierska D, Thomassen LC, Lison D, Martens JA, Hoet PH. The nanosilica hazard: another variable entity. Part Fibre Toxicol 2010;7:1.

[53] Capeletti LB, de Oliveira LF, Gonçalves K de A, de Oliveira JFA, Saito Â, Kobarg J, et al.. Tailored silica-antibiotic nanoparticles: overcoming bacterial resistance with low cytotoxicity. Langmuir 2014;30:7456-64. http://dx.doi.org/10.1021/ la4046435.

[54] Wehling J, Volkmann E, Grieb T, Rosenauer A, Maas M, Treccani L, et al. A critical study: assessment of the effect of silica particles from 15 to $500 \mathrm{~nm}$ on bacterial viability. Environ Pollut 2013;176:292-9. http://dx.doi.org/10.1016/j.envpol. 2013.02.001.

[55] Martínez-Castañón GA, Niño-Martínez N, Martínez-Gutierrez F, Martínez-Mendoza JR, Ruiz F. Synthesis and antibacterial activity of silver nanoparticles with different sizes. J Nanopart Res 2008;10:1343-8. http://dx.doi.org/10.1007/s11051-0089428-6.

[56] Gammoudi I, Mathelie-guinlet M, Morote F, Beven L, Moynet D, Grauby-heywang C, et al. Morphological and nanostructural surface changes in Escherichia coli over time, monitored by atomic force microscopy. Colloids Surf B Biointerfaces 2016;141:355-64. http://dx.doi.org/10.1016/j.colsurfb.2016.02.006.

[57] Livadaru L, Kovalenko A. Fundamental mechanism of translocation across liquidlike membranes: toward control over nanoparticle behavior. Nano Lett 2006;6:78-83. http://dx.doi.org/10.1021/nl052073s.

[58] Yang L, Wang K, Tan W, He X, Jin R, Li J, et al. Atomic force microscopy study of different effects of natural and semisynthetic $\beta$-lactam on the cell envelope of Escherichia c oli. Anal Chem 2006;78:7341-5. http://dx.doi.org/10.1021/ ac0604890.

[59] Leclère P, Rasmont A, Brédas JL, Jérôme R, Aimé JP, Lazzaroni R. Phase-separated microstructures in "all-acrylic" thermoplastic elastomers. Macromol Symp 2001;167:117-37. http://dx.doi.org/10.1002/1521-3900(200103) $167: 1<117::$ AID-MASY117 > 3.0.CO;2-1.

[60] Abraham T, Schooling SR, Beveridge TJ, Katsaras J. Monolayer film behavior of lipopolysaccharide from Pseudomonas aeruginosa at the air-water interface. Biomacromolecules 2008;9:2799-804. http://dx.doi.org/10.1021/bm800562r.

[61] Li A, Lee PY, Ho B, Ding JL, Lim CT. Atomic force microscopy study of the antimicrobial action of Sushi peptides on Gram negative bacteria. Biochim Biophys Acta BBA - Biomembr 1768;2007:411-8. http://dx.doi.org/10.1016/j.bbamem. 2006.12.010.

[62] Meincken M, Holroyd DL, Rautenbach M. Atomic force microscopy study of the effect of antimicrobial peptides on the cell envelope of Escherichia coli. Antimicrob Agents Chemother 2005;49:4085-92. http://dx.doi.org/10.1128/AAC.49.10.40854092.2005.

[63] El Badawy AM, Silva RG, Morris B, Scheckel KG, Suidan MT, Tolaymat TM. Surface charge-dependent toxicity of silver nanoparticles. Environ Sci Technol 2010;45:283-7.

[64] Hartlen KD, Athanasopoulos APT, Kitaev V. Facile preparation of highly monodisperse small silica spheres ( 15 to $>200 \mathrm{~nm}$ ) suitable for colloidal templating and formation of ordered arrays. Langmuir 2008;24:1714-20. http://dx.doi.org/10. 1021/la7025285.

[65] Gaudon M, Basly B, Fauque Y, Majimel J, Delville MH. Thermochromic phase transition on $\mathrm{CuMo}_{0.9} \mathrm{~W}_{0.1} \mathrm{O}_{4} @ \mathrm{SiO}_{2}$ core shell particles. Inorg Chem 2009;48:2136-9. http://dx.doi.org/10.1021/ic802057c.

[66] Bolshakova AV, Kiselyova OI, Filonov AS, Frolova OY, Lyubchenko YL, Yaminsky IV. Comparative studies of bacteria with an atomic force microscopy operating in different modes. Ultramicroscopy 2001;86:121-8. 